\title{
Ćwierć wieku przed czasem. O etiudzie Henryka Kluby Ocalenie
}

Ocena dokonującego się w połowie lat 50. zasadniczego przełomu w życiu kulturalnym rządzonej przez komunistów Polski - a epicentrum tego przełomu wiązało się $\mathrm{z}$ wydarzeniami Października 1956 roku - z każdą upływającą dekadą coraz bardziej się zmienia, jego kapitalne znaczenie blaknie, a ranga się umniejsza. Odrzucenie socrealizmu - dla twórców tamtego czasu sprawa bodaj najważniejsza - ze współczesnej perspektywy okazuje się mniej radykalne, a odkrywanie prawdy o otaczającej rzeczywistości - bardziej powierzchowne i ściśle reglamentowane. Legendarne utwory literackie $\mathrm{z}$ tamtych lat - poemat Ważyka, powieści Andrzejewskiego czy opowiadania Brandysa - odczytywane niegdyś jako wstrząsający rozrachunek, okazują się raczej unikiem, starannym ominięciem tego, co najbardziej bolesne. Dokumentalne filmy spod znaku czarnej serii odsłaniają swój naiwny dydaktyzm i bezwzględnie respektowane sfery tabu. „Piekielnie ostra jest dawka prawdy zawarta w tych filmach - pisała wówczas Agnieszka Osiecka. - To szokuje. [...] Uczy buntu, wrażliwości na zło”[1]. Dziś zapał autorki wydaje się nazbyt egzaltowany, przesadzony, może nawet wzbudzać uśmiech. Podobnie rzecz ma się z filmami szkoły polskiej. Nie dotykają one spraw najbardziej zapalnych, a jeśli już, to - jak np. w Popiele i diamencie Andrzeja Wajdy (1958) - w sposób ambiwalentny, nie do końca jasny. Ich ranga artystyczna nie podlega dyskusji, lecz ich relacja z prawdą niedawnej przeszłości musi być odczytywana jako skomplikowana.

Oczywiście oceny podejmowane z perspektywy drugiej dekady XXI wieku, z perspektywy wyraźnie odmiennych uwarunkowań politycznych zawsze zawierają w sobie pierwiastek intelektualnej uzurpacji. Dalece zmieniła się przecież i wciąż się zmienia świadomość zaistniałych sytuacji. Znamy podstawowe fakty, obcujemy z wieloma relacjami świadków. IPN odnajduje, a potem z oporami i trudem, ale jednak ekshumuje i identyfikuje dotąd bezimienne, ukryte przed ludzkim okiem ofiary stalinowskich zbrodni. Powstają szczegółowe historyczne monografie, trochę literatury, filmy. Cenzura, jeśli się pojawia, to nieoficjalna, trochę nieskuteczna, trochę liberalna. Ale w tej zmieniającej się ocenie nie chodzi o zdeprecjonowanie osiągnięć okołopaździernikowej odwilży, o jakiś sąd nad jej bohaterami, choć symptomatyczne, że w większości byli to po prostu „nawróceni” wykonawcy socreali-

[1] A. Osiecka, Wiosna polskiego filmu, „Sztandar Młodych" 1957, nr 76. 
stycznej normy, uzupełnieni o pewną ilość debiutantów. Istotne jest raczej wskazanie generalnego statusu peerelowskich „odnów”, zawsze ściśle kontrolowanych i samoograniczających się.

Trzeba też powiedzieć, że twórcy z drugiej połowy lat 50. siłą rzeczy lepiej niż ich następcy, a nawet lepiej niż oni sami parę dekad później, na pewno też lepiej niż „poinformowani historycznie” twórcy współcześni, wyczuwali ducha tamtego czasu. Znali konkret, obracali się w nim, byli na bieżąco. Ich reakcje były gorące, nieprzewidywalne, nieprzefiltrowane przez to, co już zostało opowiedziane.

W opublikowanym w 2014 roku tekście zmarły w tym samym roku uczestnik tamtych zdarzeń, popaździernikowy debiutant Marek Nowakowski dość ostro odnosi się do ówczesnej literatury rozrachunkowej:

Były to dramaty apologetów systemu, cierpliwie i wiernie stosujących się do zaleceń rządzącej partii. Ci apologeci często sami podlegali okrutnym represjom jako ofiary odchyleń trockistowskich, prawicowych, nacjonalistycznych i innych. Wymuszano na nich przyznawanie się do niepopełnionych win, samooskarżenia i oskarżenia wyimaginowanych wspólników. Torturowani psychicznie i fizycznie przyjmowali ciężar niepopełnionych win i zbrodni, poświęcali się dla partii, byli jej karnymi, ślepo oddanymi żołnierzami. To były tzw. błędy i wypaczenia systemu komunistycznego. [...] Takimi bohaterami zaludniła się „literatura obrachunkowa”. Komunistami, którzy przedtem tak samo bywali katami dla innych, tępili bezlitośnie wymyślonych wrogów, żeby zmienić rolę i zostać ofiarami innych katów. [...] [Literatura - przyp. A.S.] Odsłaniała ponurą rzeczywistość w ograniczonym zakresie.

Potem definiuje jej najboleśniejszy brak:

W owym literackim obrachunku ze stalinowską przeszłością nie powstał ani jeden utwór dotyczący losów uciemiężonego przez komunizm społeczeństwa, jego cierpień, tragedii, wyrzeczeń. Nie było miejsca dla opisania dramatu ludzi z AK, WiN, NSZ. Nie znalazła się nawet najmniejsza wzmianka o powojennym antykomunistycznym powstaniu i losach niezłomnych żołnierzy walczących bez nadziei, ale z honorem, o wolną Polskę. Ci bohaterowie pozostali z odium „bandytów”, „zdrajców”.

Aż wreszcie stara się odtworzyć własne odczucia sprzed niemal sześćdziesięciu lat:

Pamiętam swoje wrażenia z lektury „Matki Królów” i innych tego typu utworów, które przeczytałem po 1956 r. Niedosyt. Fałszywy ton. Wrażenie amputacji. Cała splątana, wielostronna rzeczywistość Polski powojennej, którą jakoś poznałem i trochę doświadczyłem, pozostała „terra incognita”[2].

$\mathrm{Z}$ tego niezachęcającego, $\mathrm{z}$ publicystyczną swadą uproszczonego pejzażu, trochę sobie przecząc, wyjmuje jednak Nowakowski jeden utwór, a mianowicie opowiadanie Aleksandra Ścibora-Rylskiego Morze Sargassa, opublikowane w dwóch numerach tygodnika „Nowa

[2] M. Nowakowski, Morze Sargassa, http://niezale-

zna.pl/58633-morze-sargassa [dostęp 10.11.2014]. 
Kultura", ostatnim z roku 1956 i pierwszym z 1957. To wyróżnienie prozy niegdysiejszego akowca i powstańca warszawskiego, po wojnie dzielnego wyrobnika socrealizmu, późniejszego wziętego scenarzysty, m.in. autora literackiego projektu Człowieka $z$ marmuru Andrzeja Wajdy (1976), reżysera i pisarza, wydaje się oczywiste. Jest to tekst, który nawet ukazując się współcześnie, wzbudziłby zapewne uznanie swoją wiwisekcją stalinowskiej rzeczywistości. W jaki sposób przedostał się do druku jesienią 1956 roku, trudno byłoby już w szczegółach odtworzyć. Reakcją była bardzo emocjonalna i mimetyczna lektura części czytelników, która wymogła na pisarzu dodatkowe wyjaśnienie, iż fabuła jest całkowicie fikcyjna. Pojawiły się też żywe i raczej nieprzychylne komentarze krytyków, także tych, jak np. Jan Błoński, uznawanych za wybitnych. Ścibor został zaatakowany za sprokurowanie tekstu socrealistycznego á rebours, za brak refleksji moralno-estetycznej i historiozoficznej, za diabolizację stalinizmu[3]. Przewrotnym potwierdzeniem demaskatorskiej celności dzieła mógłby być fakt, że nigdy później nie zostało ono już wydrukowane, ani w Peerelu, ani w III RP. O Morzu Sargassa szybko i skwapliwie zapomniano. Nie pamiętał o nim Wajda, konstruując zakończenie swego Pierścionka z orłem w koronie (1992)[4]. A szkoda. Nie pamiętał również Marek Nowakowski. W 2013 roku ktoś przyniósł mu kserokopię opowiadania i stąd wyżej cytowany artykuł.

Realizm tekstu, dotykalność przedstawionego w nim świata, które tak bardzo uwierały recenzentów, a także znakomita konstrukcja dramaturgiczna, zarysowanie konfliktów, kreacja głównej bohaterki - postaci wewnętrznie bardzo dynamicznej - wszystko to decyduje o jego niebagatelnym potencjale adaptacyjnym, przydatności dla obróbki scenarzysty filmowego. Autor, któremu to audiowizualne medium było szczególnie bliskie, natychmiast zdał sobie z tego sprawę. Chcąc wykorzystać dobrą, zdawałoby się, koniunkturę, jeszcze zimą 1957 roku złożył scenariusz Morza Sargassa w Zespole Iluzjon, modyfikując w kilku miejscach treść opowiadania, ale nie osłabiając jego wymowy[5]. Jak należało się spodziewać, srodze się przeliczył. Projekt ten nie doczekał się nawet wszczęcia formalnej procedury decyzyjnej w ramach ówczesnych struktur kinematograficznych. Obecnie istnieje w postaci manuskryptu, który można zobaczyć jedynie w archiwach Filmoteki Narodowej[6].

Nie jest jednak tak, by opowiadanie nie miało swego ekranowego żywota, owszem bardzo skromnego, ale zarazem istotnego, a gdy wydobywa się ów żywot z zapomnienia, nawet szokującego. Jeszcze w pierwszej połowie 1957 roku student czwartego roku reżyserii ówczesnej łódzkiej PWSF Henryk Kluba zrealizował osiemnastominutową etiudę zatytułowaną Ocalenie (tym słowem kończy się utwór wydruko-

[3] Dyskusję tę szerzej omawia Tadeusz Lubelski. Idem, Legenda Morza Sargassa, w: Październik 1956 $w$ literaturze i filmie, red. M. Zawodniak i P. Zwierzchowski, Bydgoszcz 2010, s. 202-205.
[4] Ibidem, s. 211.

[5] Ibidem, s. 206-208.

[6] Ibidem. 
wany w „Nowej Kulturze”), będącą w ścisłym tego terminu znaczeniu adaptacją Morza Sargassa.

Fakt, że ekranizacja ta powstała w łódzkiej Filmówce, nie powinien dziwić. Jeśli bowiem gdziekolwiek, to właśnie tam. W latach 1956-57 studenci tej uczelni nakręcili co najmniej kilka etiud, które nie tyle może swym zasięgiem tematycznym (tym bardziej poziomem artystycznym), co odwagą krytycznej penetracji przekroczyły granice obowiązujące w oficjalnej kinematografii[7]. O takich możliwościach przesąadzała większa swoboda, a więc i mniej ścisłej kontroli nad produkcją filmów, wynikająca $\mathrm{z}$ bardzo ograniczonej dystrybucji, ale także z postaw niektórych nauczycieli. Opiekunem Ocalenia był Antoni Bohdziewicz.

Natomiast fakt, że adaptatorem został właśnie Kluba, to pewna niespodzianka. Jeszcze kilka miesięcy wcześniej nakręcił sztampową i w najwyższym stopniu konformistyczną laurkę na część Milicji Obywatelskiej, etiudę Trzy protokoły (1956). W tym zaś utworze poważył się wkroczyć na teren, wydawałoby się, niemożliwy, poddany szczególnie silnemu tabu. A taki teren stanowiły bez wątpienia kulisy pracy „resortu” oraz związane z nimi kulisy losów niegdysiejszych wojennych bohaterów. Był jedynym, który się wówczas na to zdecydował. Później okazało się, iż autor Chudego i innych potrafi balansować między sprzecznościami, tak jako artysta, jak i nauczyciel czy urzędnik. Został długoletnim profesorem PWSFTviT, jej rektorem i twarzą, a na pewien czas również oficjelem peerelowskiej kinematografii.

Sam film, kiedy ogląda się go bez znajomości literackiej podstawy, jest nieco enigmatyczny, chwilami nawet dezorientujący. Padające w rozpoczynającej go scenie przesłuchania słowa głównej bohaterki, Myszki, są niezwykle trudne do interpretacji. „Wytłumaczcie mi coś. Dlaczego Husarz..., dlaczego się nim tak bardzo interesujecie? To jest człowiek już prawie nasz" - pyta dziewczyna, której twarz rozjaśniona jest skierowanym wprost na nią światłem stolikowej lampki i wobec której śledczy zachowuje się obcesowo i wrogo, choć jeszcze nie brutalnie. To przyjdzie później. Do końca owo „nasz” nie jest w pełni jasne. Co to znaczy w towarzystwie, które wciąż honoruje się powstańczymi stopniami wojskowymi lub konspiracyjnymi pseudonimami? Co to znaczy wobec agenturalnych raportów przeglądanych jednocześnie przez ubeka i oko kamery? Cała wewnętrzna ewolucja postaci, jej spojrzenia na świat, dojrzewanie do wiedzy o prawdziwych realiach stalinizmu, a zatem kwestia, która zajmuje poczesne miejsce w tekście opowiadania, tutaj pozostaje skryta. Jej ujawnienie wymaga głębszej analizy i bardzo dobrej orientacji w kontekście, a i tak pozostanie tylko niepewną, szkicową sugestią.

Kolejną niejasnością okazuje się status relacji Myszki i Husarza, mieszkających wspólnie, ale przecież nie będących nawet nieformalnie

[7] J. Preizner, PRL w obiektywie studentów łódzkiej Filmówki w latach 1949-1960, Kraków 2007, s. 334353; A. Szpulak, Etiudy „społecznego zwiadu”.O szkol- nych krewniaczkach filmów czarnej serii, „Images” 2014, vol. XIV, nr 23, s. 153-164. 
parą, nie zbliżających się do siebie, sypiających osobno, skrępowanych swoją obecnością. Problem ten spowodowało wyeliminowanie niezwykle ważnej w opowiadaniu postaci, Czapli, siostry Husarza, która mieszkała w tym samym jednopokojowym mieszkanku. Strata jest istotna, gdyż kulejąca sanitariuszka nie tylko uzasadniała swą obecnością owo skrępowanie, ale przede wszystkim wnosiła bardzo wiele życia do tego świata, generowała silny konflikt. Bez niej ubywa ambiwalencji w obrazie relacji między bohaterami, a także w nich samych.

Problemy te wynikają rzecz jasna z metrażu szkolnej etiudy. Wymógł on skrótowość przekazu, spowodował wszystkie braki i elipsy. Utwór składa się z siedmiu sekwencji, z których każda, jak łatwo obliczyć, trwa średnio tylko około dwóch i pół minuty. Jak na materię Morza Sargassa to niezwykle mało. Mimo to nie można zdeprecjonować lub zlekceważyć filmu Kluby, tak pod względem artystycznym, jak i nieco szerszym, historycznofilmowym.

Jeśli chodzi o ów pierwszy aspekt, przekonuje o tym bardzo ciekawa, rozegrana na wielu rejestrach aktorskiej ekspresji kreacja Janiny Traczykówny jako Myszki. Fenomen młodej kobiety, wewnętrznie rozdartej, ale zarazem dojrzewającej, kochającej i ulegającej wynikającemu z osaczenia lękowi, pragnącej bliskości i milczącej, został w Ocaleniu zarysowany z dużą intensywnością. Dodatkowo sprzyjał temu fakt niemal idealnej adekwatności fizis aktorki oraz literackiego opisu postaci, a także - co stosunkowo ważne - jej pseudonimu. Myszka prawie nie schodzi z ekranu. Często jest filmowana w zbliżeniach, czasem w detalach. Kamera śledzi jej odruchy, malujące się na twarzy ślady walki wewnętrznej i narastającego poczucia beznadziejności, momenty ożywienia i zamknięcia w sobie. Jej głos - na ogół rzeczowy, zaskakująco mocny i nawet nieprzyjemny w zestawieniu $\mathrm{z}$ eteryczną fizjonomią zmienia się w chwilach obrazujących intensywność relacji z byłym powstańczym dowódcą, staje się głębszy, delikatniejszy, nieomal uległy, choć bez nadziei na wysłuchanie.

Medium aktora to największa siła filmu, gdyż generuje grę emocji i sensów, ale przecież nie tylko ono. Bardzo ciekawie są tu kreowane przestrzenie cienia i światła. Oczywiście przy ich analizie trzeba brać poprawkę na stan kopii oraz jakość materiałów, z jakich została wykonana, a nawet na jakość sprzętu używanego przez realizatorów. Wyraźnie widoczna jest jednak kreacja przestrzeni za pomocą walorów jasność-ciemność. Z wyjątkiem ostatniej sceny cała akcja rozgrywa się nocą lub w zamkniętych, pozbawionych okien pomieszczeniach. Jeśli wnętrze mieszkania (przynajmniej w scenie z rowerem) czy knajpy jest oświetlone w miarę neutralnie, to przestrzeń „urzędu” - pokoju przesłuchań oraz przylegającej do niego łazienki - zostaje pogrążona w gęstym półmroku lub nawet w prawie całkowitej ciemności. Rozświetla ją tylko mdławy blask lampki skierowany na twarz byłej łączniczki, a także zapalona na chwilę żarówka, kiedy bohaterka ma za zadanie doprowadzić swój wygląd do porządku. W scenach tych wyraźnie widać jedynie twarz Myszki. Już jednak oblicze śledczego, także rejestrowane 
przez kamerę, okazuje się funkcjonować wyłącznie w półmroku. Fragmenty te odsłaniają symboliczny status świata, w który jest zmuszona wkroczyć bohaterka.

Świat ten często jest pokazywany w detalach - czubki butów, kartka z raportem konfidenta, dłoń, rowerowa szprycha. Chwyt ten doskonale oddaje atmosferę osaczenia, opresji, kiedy nie widzi się świata jako w sposób naturalny zintegrowanej całości. Przypomina on rozbite lustro. Każdy jego kawałek zaś może być odczytany jako świadectwo zagrożenia.

Ważniejszym od tych wszystkich zabiegów estetycznych pozostaje jednak ów szerszy, historycznofilmowy aspekt. To on stanowi źródło konsternacji, zaskoczenia czy nawet szoku.

Jako się rzekło, Kluba pominął wiele wątków i obrazów obecnych w opowiadaniu Ścibora-Rylskiego. Ale są też takie, które dodał. A jeden z nich okazuje się szczególnie ważny. Autor prozy pokazuje śledczego, który bierze do ręki leżącą na szafie, a przeznaczoną do bicia przesłuchiwanej kobiety szprychę, a bezpośrednio potem przenosi nas do łazienki, w której bohaterka dochodzi do siebie po brutalnym skatowaniu. Reżyser natomiast postępuje inaczej; umieszcza w swoim filmie także scenę kaźni. Raczej ją słyszymy niż widzimy, gdyż po pierwszym uderzeniu Myszka znika z kadru, lecz to zdaje się nawet pogłębiać ekspresję. To pierwszy taki obraz w dziejach polskiej kinematografii. Następny pojawi się dopiero po ćwierćwieczu.

$\mathrm{W}$ polskim filmie zdającym sprawę $\mathrm{z}$ doświadczenia czasu stalinizmu można wyróżnić trzy strategie, zarysowujące się już w czasie Peerelu, kiedy to poczynając od Człowieka z marmuru, zaczęły pojawiać się utwory rozrachunkowe. Strategie te dominują do dzisiaj. Poza obszarem ich oddziaływania - przynajmniej do pewnego stopnia - znalazł się tylko Rewers Borysa Lankosza (2009). Pierwsza, najmocniej reprezentowana strategia została oparta na intelektualnym dyskursie racji etycznych i politycznych. Druga, rzadziej używana - na obrazowaniu przeżycia indywidualnego, sprywatyzowanego. Trzecia zaś, przynajmniej do roku 2006 stanowiąca ewenement, nakazywała skupiać się na prezentacji traumatycznego przeżycia terroru i zarazem na rozbrajaniu traumy.

Początkiem i zarazem kwintesencją tej ostatniej zdaje się być Przesłuchanie Ryszarda Bugajskiego (1982). Następne jej realizacje pojawiły się dużo później, choć tym razem w sporej ilości - począwszy od Inki 1946 Wojciecha Tomczyka i Natalii Korynckiej-Gruz (2006). Bezpośrednie obrazy przemocy, za syntezę których można uznać sekwencję montażową z finałowej części Róży Wojciecha Smarzowskiego (2011), opanowały ekrany dopiero w ostatnich ośmiu latach. Wcześniej były objęte skwapliwie respektowanym tabu. W latach 1982-2006 tylko w jednym filmie - Kuchni polskiej Jacka Bromskiego (1991) - pojawiły się dwie krótkie sceny, które naocznie dotykały rzeczywistości terroru. To niemal ćwierć wieku, a lwia część tego czasu przypada na trwanie III RP.

W tym kontekście pojawienie się Ocalenia już w 1957 roku, a więc pięćdziesiąt lat przed zasadniczym przełomem w obrazowaniu 
działalności stalinowskiego UB, w chwilach pierwszej „socjalistycznej odnowy”, która przecież starannie unikała tematyki „resortowej”, musi budzić emocje i modyfikować opis historycznofilmowego procesu. Oczywiście etiuda Kluby jest skromna i prawie nieznana, ale nie można uznać jej za niebyłą.

A koncentruje się ona na zagadnieniu terroru nawet znacznie wyraźniej niż opowiadanie niespodziewanie opublikowane w „Nowej Kulturze". Oprócz wskazania podstawowej roli ubeka w dezintegracji mikroświata bohaterów, tekst literacki rysuje szerszą perspektywę społeczną, kreuje dyskurs polityczno-historyczny, w większym stopniu uruchamia kontekst indywidualnej wrażliwości, obrazuje proces dojrzewania świadomości. Film natomiast skupia się na centralnym obrazie przesłuchania bohaterki, przeżyciu bólu i strachu. Od niego zaczyna i z niego czyni punkt kulminacyjny. Nie mając dostępu do wewnętrznego świata Myszki, jako widzowie jesteśmy zmuszeni zwracać baczniejszą uwagę na zewnętrznie widoczne doznania fizyczne, w nich odnajdywać podstawową motywację podjętych decyzji. Świat zostaje okrojony do zacienionych pomieszczeń dzielnicowego UB - reszta przestrzeni to coś w rodzaju przyległości. W istocie więc Ocalenie okazuje się jakby wstępnym wariantem późniejszego, znacznie bardziej rozbudowanego Przestuchania. A więc choćby tylko wyraźne odnotowanie jego powstania wydaje się rzeczą konieczną dla uzyskania pełnego wizerunku obecności tej tematyki w filmie.

Pojawienie się tej etiudy wpływa też - w ograniczonym stopniu, rzecz jasna - na ocenę obrazu filmowego oblicza okołopaździernikowej „odwilży”. Jawnie złamała ona bowiem podstawową i ściśle przestrzeganą zasadę, iż kwestia ubeckich śledztw, sądowych wyroków i rehabilitacji może być poruszana jedynie przez aluzję bardzo ogólnej natury, bez konkretnych odniesień, w żadnym natomiast wypadku nie może zostać pokazana. 